\title{
UKRAINIAN-POLISH POLITICAL RELATIONS IN THE CONTEXT OF OPPOSING IMPERIAL ENCROACHMENTS FROM RUSSIA
}

\section{Sytnyk O. M.}

\section{INTRODUCTION}

History has the property of teaching. Educate people, societies, nations, and even nations. And if this science is ignored, the reckoning is too harsh. Unfortunately, there are a lot of examples of this in the historical development of mankind. For Ukraine and Poland, starting in the second half of the XVIIIth century, history prepared a series of cruel trials that continue to this day. Starting from the deprivation of statehood of both our countries by the Moscow-Kremlin regime, tearing their territory apart, destroying the national and spiritual elite and ending with hybrid zombies, the goal of which is to deform the consciousness of Ukrainians and Poles.

\section{Historical review of Ukrainian-Polish political relations in terms of opposing imperial encroachments by Russia}

Even in the beginning of the twentieth century, Ivan Franko, with deep knowledge of the whole range of problems of Ukrainian-Polish relations, came to the paradoxical conclusion that there are no two peoples in the entire Slavic world, from the point of view of political and spiritual life, they are so much fused together and were so closely interconnected, and at the same time, they avoided each other as much as Ukrainians and Poles. At that time, Ukrainians and Poles were, in general, in the same "starting" political conditions of the absence of national statehood, with $80 \%$ of Ukrainian and more than $55 \%$ of Poles being subjects of the Romanov empire, $20 \%$ of Ukrainian and $25 \%$ of Poles being Habsburg empires, the rest of the Poles inhabiting the Hohenzollern possessions. But even with such seemingly bleak prospects, the views of most Polish politicians were based on the conviction that it was necessary to revive the Polish-Lithuanian Commonwealth in its historical ("Jagiellonian") borders, where Ukrainian lands (at least right-bank) would be an organic component of the future republic. One of the most popular concepts was formulated by the leader of the National Democratic Party G. Dmovsky ${ }^{1}$.

1 Головченко В. Українсько-польські відносини: формування міждержавних взаємин у дусі Євроатлантичного партнерства. WISŁA I DNIEPREM/НАД ВICЛOЮ I ДНIПРОМ. Торунь-Київ: Міжнародний науково-освітній консоричум імені Люсьєна Февра, 2017. Т. 1. С. 43. 
Which the main driving force of national development was considered rational to fight for their rights, religion and cultural development of the poles. Moreover, leading tool was considered not armed struggle, and the gradual cultural development of the Polish nation.

History also tends to repeat itself. Especially in cases where a particular people or nation does not make proper conclusions regarding errors and omissions. This is primarily related to the national liberation struggle of 1917-1921 years, when, being in a kind of bifurcation point, after centuries of statelessness, which was simultaneously the consequence and the cause of disintegration of the Ukrainian nation, Ukraine had a unique chance of independence. However, a number of objective and subjective circumstances, that Ukrainians could not be reached. How dare you the terror, starvation and the total destruction of Moscow occupiers, the most conscious representatives of the Ukrainian nation, including modern aggression.

Y. Dashkevich noted that Ukraine today has become a testing ground for the implementation of others, also very bloody and paid for by the loss of the national independence, ideological constructions. This was highlighted in 1917-1921 and subsequent years ${ }^{2}$. First, socialist ideas, and later the Bolshevik ideology leveled almost everything national-spiritual in Ukraine, which was not destroyed for centuries by the Russian autocracy. The policy of the Russian authorities regarding Poland was similar. Moreover, Russia was especially active in terms of using the principle of "divide and conquer". For centuries, the Russian autocratic, and then the Bolshevik authorities, used against the neighboring peoples suppressed by it a whole complex of methods and means, which are now called the "hybrid war".

The Bolshevik revolution of 1917 and the formation of the RSFSR added arguments to the Polish national democrats. Upgrading an idea antemurale (Poland is an outpost of Western Christianity in its confrontation with the East), supporters of $R$. Dmowski began to see in their activities an important mission in protecting Western civilization from the threat of exporting a "world revolution" from Moscow ${ }^{3}$. Thus, in the political doctrines of one of the most influential political forces of Polish society in the first half of the twentieth century - national democracy - there was no place for independent Ukraine, because, in their opinion, Ukraine would pursue a German policy towards the threat of

\footnotetext{
2 Дашкевич Я. Україна у вогні ідеологій. Кісь Р. Фінал Третього Риму (Російська ідея на зламі тисячоліть). Львів: Вид-во отців Василіян «Місіонер», 1998. С. IV.

${ }^{3}$ Tomaszewski J. Kresy Wschodnie w polskiej mysli politycznej XIX i XX w. Miedzy Polska etniczna a historyczna. Polska mysl polityczna XIX i XX wieku. T. 6. Warszawa, 1988. S. 171-172.
} 
Russian imperialism. No less influential and popular than the "incorporation concept" of national democrats was the "federalist program" of the "head of state" in 1918-1922 and the actual leader of the "reorganization" regime of 1926-1935, Y. Pilsudsky. He defended the idea of forming a federation of Poland with Ukraine, Belarus and Lithuania liberated from Russian rule. This would lead to the formation of a geopolitical "corridor", which was supposed to protect the Second PolishLithuanian Commonwealth from direct aggression from the "red" or "white" Russia (if the latter won the Civil War of 1918-1920). At the same time, in Poland, again, the Kholmshchina, Western Volhynia along the $r$. Styr and Lviv region. In the rest of Eastern Galicia and in Volhynia, it was proposed to grant the Polish minority national-cultural autonomy as part of the Ukrainian People's Republic (UNR). In the era of the Ukrainian Revolution of 1917-1920, Ukrainian-Polish relations first received models of modern interstate relations with all the relying attributes on relatively equal subjects of international law. As for the Western Ukrainian People's Republic, occupied by the newly emerged Polish state during the Ukrainian-Polish war of 1918-1919, the Poles, unfortunately, could not see in the patriotic upsurge of the national liberation struggle of the UkrainianGalicians, the desire to create their own state, that is, the phenomenon close to the Polish revival. For them, it was a leash of an anti-Polish speech that occurred on the originally (as they thought) ethnically and culturally Polish lands and which threatened the territorial integrity of the revived Polish-Lithuanian Commonwealth. The Polish side could not allow the formation of an independent Ukrainian state in Eastern Galicia, and in this all the political forces of Polish society were united. The situation was different with the Dnieper Ukraine, because from the geopolitical and military-strategic point of view, the UPR was objectively interested in establishing allied relations with the Second Polish-Lithuanian Commonwealth. According to V. Golovchenko, the result of the "Kiev campaign" by Y. Pilsudsky was the implementation not so much of his federalist program as the concept of national democrats. In the interwar period, the problem of the attitude towards the Ukrainians who became part of Poland as a result of the occupation of the Western Ukrainian lands came to the fore for Warsaw, and the strategy of assimilating them was adopted 4 . "Poland for the Poles" - this is how you can briefly define the national policy of the People's Democracy Camp in an effort to turn the

4 Головченко В. Українсько-польські відносини: формування міждержавних взаємин у дусі Євроатлантичного партнерства. WISŁA I DNIEPREM/НАД ВICЛOЮ I ДНIПРОМ. Торунь-Київ: Міжнародний науково-освітній консоричум імені Люсьєна Февра, 2017. Т. 1. С. 43, 44. 
state territory of the Polish-Lithuanian Commonwealth into national Polish territory ${ }^{5}$. In this way national Democrats had hoped to prove that the Western lands to Poland forever secured, and thus, to put an end to the hopes of Ukrainians for an independent state. At the same time, the competing "federalist concept" devotees of J. Pilsudski in 1920-1930th years became known as the doctrine of "Polish prometheism". The foreign policy of the Second Polish Republic prometeisti viewed through the prism of future conflict the civilized West, to which they reckoned and Poland, with the Communist Soviet Union. The result of this collision, as expected, was to be the disintegration of the multinational Bolshevik Empire. Released, but according to "prometiste" politically and nationally immature peoples need help in the process of nation-state. Prometeisti criticized the Warsaw Treaty of 1920 for ignorowanie the interests of the Galician Ukrainians, that led to the failure of the "Kiev campaign" of 1920. In the new phase, according to them, the Galicians can be not only a catalyst for the movement for the education of "great Ukraine" on the ruins of the Bolshevik Empire - they are the vanguard of a new liberation campaign in the East ${ }^{6}$. According to I. Sribnyak, leading Ukrainian politicians supported the Prometheus project of Y. Pilsudsky, as it was aimed at weakening Bolshevik Russia by supporting the desire for independence of the peoples previously enslaved by Moscow ${ }^{7}$.

The Second World War marked the beginning of one of the nitragic periods in the history of Ukrainian-Polish relations. As a result of double aggression against Poland by Nazi Germany and the Stalinist USSR and the distribution of Polish territories between them on the basis of secret protocols to the Nonaggression Pact of August 23, 1939 and the Treaty of Friendship and Borders of September 28 of the same year, the Western Ukrainian lands became part of Soviet Ukraine. In this situation, the Polish government, which found itself in exile in London, faced the problem of developing a new policy on the Ukrainian issue. In the emigrant government there were supporters of both the ideas of federalism, in particular the Prometheists, and traditional national democrats. The Polish government announced its position on the Ukrainian issue in a declaration of December 18, 1939, which outlined the basic principles of equality and

\footnotetext{
${ }^{5}$ Tomaszewski J. Kresy Wschodnie w polskiej mysli politycznej XIX i XX w. Miedzy Polska etniczna a historyczna. Polska mysl polityczna XIX i XX wieku. T. 6. Warszawa, 1988. S. 168.

6 Головченко В. Українсько-польські відносини: формування міждержавних взаємин у дусі Євроатлантичного партнерства. WIStA I DNIEPREM/НАД ВICЛOЮ I ДНIПРОМ. Торунь-Київ: Міжнародний науково-освітній консорииум імені Люсьєна Февра, 2017. Т. 1. С. 45, 46.

Срібняк I. Українська політична еміграція в міжвоєнній Польщі: шляхи формування, особливості діяльності, подальша доля. WISEA I DNIEPREM/HАД ВICЛOЮ I ДНIПРОМ Польща і Україна в європейській перспективі - минуле і сучасність. Toruń-Saragossa: Miжнародна асочіація істориківархівістів, 2015. T. 4. С. 158.
} 
justice in relation to national minorities and proclaimed the struggle for the return of the lost "eastern regions" .

One of the unfortunate consequences of the tough decisions the issue of borders in the interwar period (in particular the fact that more than five million Ukrainians were on the territory of Poland, and part ethnic poles made up a significant percentage of the population of Volyn) were the events that took place in 1943 in Volyn. However, the tragic events that took place there have used primarily the Soviet Communist leaders, and in the modern era of Pro-Russian politicians strongly used this historical tragedy to spoil Ukrainian-Polish political relations.

Seeing from the time of the national liberation uprising of 1794 led by Tadeusz Kosciuszko, and especially in the nineteenth century - the unity of poles and Ukrainians under the slogan "For our and your freedom!" (Za wolność naszą i waszą), the autocratic imperial power began to act insidiously - pitting Polish nationalist patriots with Ukrainian. The Bolsheviks in the twentieth century, and their followers - "Putin security officers" at the beginning of the twenty-first century achieved particular success in this.

M. Guy claims that the term "hybrid war" is simply a designation of a combination of fairly old methods and means of conducting a conventional war'. At the same time, one of the varieties of hybrid warfare was the "war of controlled chaos". This is precisely what the Bolshevik leaders used both during the national liberation struggle of 1917-1921, and during World War II. And perhaps the most telling example of this is the history of the Warsaw Uprising of 1944.

It is well known that the rebels in Warsaw expected the approach of the Red Army. But the Soviet offensive stopped, allowing the Germans to regroup and destroy the city during the suppression of the uprising. It is obvious that Stalin had the intention and ordered his marshals to wait until the Germans destroyed the Polish patriots, which Stalin did not need when building communist Poland.

By the way, Moscow radio, to a certain extent, led to an uprising against the Germans, transmitting a special message at the end of July 1944. By whose order and for what purpose this call was made on the air it is still not clear. For the sake of justice, it should be noted that a similar

8 Головченко В. Українсько-польські відносини: формування міждержавних взаємин у дусі Євроатлантичного партнерства. WISŁA I DNIEPREM/НАД ВICЛОЮ I ДНIПРОМ. Торунь-Київ: Міжнародний науково-освітній консорииум імені Люсьєна Февра, 2017. Т. 1. С. 46.

${ }^{9}$ Гай М. Россия знает, что Украина это не Афганистан, не Чечня, не Сирия. Для реальной войны в Украине, РФ должна провести колоссальную подготовку и они это делают. URL: http://patrioty.org.ua/ blogs/rossyia-znaet-chto-ukrayna-to-ne-afhanystan-ne-chechnia-ne-syryia-dlia-realnoi-voin-v-ukrayne-rfdolzhna-provesty-kolossalnuiu-podhotovku-y-ony-to-delaiut--hai-140804.html. 
call for rebellion came from London. However, London radio a few days later still did not call the rebels a "gang of criminals", as Moscow did ${ }^{10}$.

Among the SS units involved in the suppression of the Polish uprising were soldiers of the former Kaminsky brigade. A group of Russian SS men consisted of volunteers commanded by a former Red Army officer, Lieutenant Colonel (SS Obersturmbanführer) Frolov. Created back in 1941 in the Smolensk region by the repressed engineer B. Kaminsky, this military formation now totaled up to 20 thousand people. In 1944 he was turned into the twenty-ninth SS grenadier division, and B. Kaminsky himself received the rank of brigadefuhrer of the SS troops (major general).

The brutality of the Russian SS men - looting and killing of civilians caused such hatred and horror among the Poles that later, during the surrender of the rebels, one of the conditions put forward by the Germans was the removal of the Russians from the escort of prisoners. By the way, according to some reports, B. Kaminsky himself was convicted and shot on August 19 by a military court of the SS troops for falling discipline in the troops subordinate to him, robbery, etc. (according to other sources, he was killed by SD agents in the Carpathians when trying to establish contacts with the UPA). The remains of the Kaminsky brigade were later transferred to the formation of the 1st division of the Russian Liberation Army (ROA).

It is obvious that the basis for the question of assistance to Warsaw was not so military as political factors. Stalin perfectly understood the doom of the uprising without the military support of the Red Army. He realized and didn't consciously help the Warsaw, because as a politician he saw undeniable dividends in the defeat of the speech organized by the Polish emigration government opposed to him.

The attitude of the Stalinist regime towards the idea of independent Poland and, in particular, to the Craiova Army clearly manifested itself shortly after the liberation of Polish territory by the Red Army. Almost at the same time that the Germans were killing insurgents in Warsaw, the Soviet repressive and punitive bodies began "cleansing" the territory of Poland from the Army Craiova disloyal to Soviet power. According to L. Beria, I. Stalin, only for the period from October 15 to November 14, 1944, security officers arrested more than 4,200 members of the Home Army. Repressive actions continued on.

When the Red Army entered deserted and destroyed Warsaw on January 17,1945 , there was no longer any alternative to the "government"

10 Польська Прага: «російська зрада» чи «варшавська авантюра»? Український Форум. URL: http://www.ukrcenter.com/Форум/30401/Варшавське-Повстання-1944p-та-його-музей 
brought in the Soviet wagon train. The only organized opposition capable of confronting Stalinism suffered a crushing defeat. Freed from Nazism, Poland lost its independence after World War II and was plunged into the horror of totalitarianism ${ }^{11}$.

To this day, there is a myth about the participation of Ukrainians in the suppression of the uprising. Its emergence was facilitated by the Germans use of the Russian RVNA division, as well as battalions, where representatives of the Central Asian peoples served. In fact, not a single Ukrainian formation as such took part in the suppression of the Warsaw Uprising. But some Ukrainians fought against the rebels in some German units. However, for Moscow propagandists, and especially their followers from Yanukovych's entourage - like Kolesnichenkov of various kinds, the systemic task is to blame Ukrainians for all sins (such as the Volyn massacre). At the same time, the real crimes of Moscow against the Poles (Katyn, etc.) seem to fade into the background.

If the consequence of the First World War was the complete disregard on the part of large Western states of the political and state-legal interests of the Ukrainian nation, then as a result of the Second World War this was already characteristic of both Ukraine and Poland. The confrontation of two totalitarian states: Germany and the Soviet Union led to a number of tragic consequences for the Ukrainian and Polish nations. At that time, the great Western powers again ignored the possibility of the existence of a Ukrainian political nation and state independent of the USSR, and Poland, forcibly incorporated into the socialist system, actually became the political vassal of the Soviet Union. One of the most tragic pages of this period was the so-called "Ukrainian-Polish war of 1942-1947". Regarding the causes of the Ukrainian-Polish confrontation, Y. Pelensky pointed out the existence of allegations that the Ukrainian nationalist underground intended to "depolonize" the Western Ukrainian territories, in particular, for the forced eviction of the Polish population and selective fighter actions. On the other hand, the Polish government and its armed forces, the Craiova Army, tried to do everything possible to maintain the so-called state of the Polish presence on Ukrainian lands, and resorted to terrorist and military-fighter methods to implement this plan ${ }^{12}$. Victims of the bloody terorra tens of thousands of civilians $\mathrm{z}$ both sides. At first glance, quite the opposite of the London government in exile's position in the Ukrainian question was Polish left-wing forces, under the leadership of the Communists. As a tool of Stalin's diplomacy, they are recognizing the

11 Польська Прага: «російська зрада» чи «варшавська авантюра»? Український Форум. URL: http://www.ukrcenter.com/Форум/30401/Варшавське-Повстання-1944p-та-його-музей.

12 Пеленський Я. Україна в польській опозиційній публіцистиці. Подляський Казімєж. Білоруси литовці - українці: наші вороги - чи брати? Мюнхен. 1986. С. 17. 
right of Nations to self-determination, primarily disapproved of the accession of Western Ukraine to the USSR. In fact, the Polish Communists saw the USSR guarantor of their state-political existence of the future status quo restored - Third of the Commonwealth in Europe. They strongly defended the idea on the revision of the Western and Northern borders of Poland by Germany, and also about the advisability of failure in the East from napolski ethnic territories. The implementation of these plans has created the possibility of building a mono-ethnic Polish state, which at the time wanted national Democrats. So over the years 1944-1946 were implemented Ukrainian-Polish population exchange and, since September 1945, the process for Ukrainians, the so-called "UPA" had, in fact, the nature of forced deportation. Thus, international legal the results of the Second world war dramatically changed the situation in Ukrainian-Polish relations. The official doctrine in the practice of international relations and the national question the Communist Poland was the theory of proletarian internationalism, in fact, its policy towards Ukrainians was based on the lack of recognition of their liberation aspirations and focused assimilation, which has been encouraged by Moscow. To finally "solve" the Ukrainian question and to eliminate the Ukrainian national liberation movement, the Polish Communists on April 28 - August 12, 1947, carried out the action "Vistula". To more than 140 thousand Ukrainians were applied the principle of collective responsibility: from ethnic Ukrainian land to the East of the Polish Republic they were evicted and resettled in nine Western and North-Western provinces with the ultimate aim of assimilation. The deportees were under so-called administrative supervision, without the right of free movement and changes of residence. Some of such restrictions were in force until 1970-ies. During the existence of the Polish people's Republic (Poland, 1952-1989 years) Ukrainian-Polish relations were under the strict control of Moscow and was modeled from the Kremlin as the relationship between "fraternal socialist States" in the framework of Polish-Soviet relations. After the Second world war, neither in Poland nor in Ukraine did not have its own independent foreign policy, therefore, was nonexistent some full of official relations between the USSR and pnrm. On the contrary, normal communication between them was hampered by different obstacles. So, finding no way out, anti-Ukrainian sentiment and stereotypes continued to exist among the Polish public and Vice versa, the Communist elite in Poland is not only not turn away old conflicts, but also because of its authoritarian nature, further aggravated their ${ }^{13}$. However,

13 Головченко В. Українсько-польські відносини: формування міждержавних взаємин у дусі Свроатлантичного партнерства. WISŁA I DNIEPREM/НАД ВICЛOЮ I ДНIПРОМ. Торунь-Київ: Міжнародний науково-освітній консоричиум імені Люсьєна Февра, 2017. Т. 1. С. 47, 48. 
behind official relations between the NDP and the Ukrainian SSR there were other forms of communication, laying the foundation for the future strategic partnership of the already independent Ukraine and the Republic of Poland, namely dissidents, independent intellectuals, political emigration and the like.

\section{New realities of Ukrainian-Polish political relations in the process of opposing imperial encroachments by Russia}

A significant idea of the Polish conservatives in the first half of the 1990s was the so-called idea of "inter-seas", proposed by L. Mochulsky. It became a creative development of the "federalist concept" of Y. Pilsudsky and consisted in the fact that the countries of Central and Eastern Europe (the so-called "inter-seas" - the region between the Baltic and the Adriatic and the Black Sea) should be integrated as much as possible in order to preserve their independence and identity did not absorb the post-industrial West or chauvinistic Russia. At the same time, it was Ukrainian-Polish relations, according to the ideologist of the "inter-seas", that were crucial for the implementation of the entire program. But official Warsaw immediately and unequivocally determined its Central European status and clearly focused on joining all European structures and NATO. Ukraine, however, could not for political reasons, and was not socially and politically prepared for this. The Eurasian development option was discussed for a long time (according to the Russian model and by inertia), and only recently after the victory of the Revolution did dignity officially talk about the unambiguous integration of Ukraine into Europe. A model of relations between Ukraine and the enlarged EU is being developed in relations with the Republic of Poland, and in this context, the importance of Ukrainian-Polish cooperation is gaining even more weight for the entire continent, because Ukraine, as a reliable and effective partner, together with Poland form the core of stability and security in the Central Of Eastern Europe. With Poland gaining membership on NATO on March 12, 1999, and on May 1, 2004, in the EU, the nature of Ukrainian-Polish relations began to change qualitatively. Despite a number of internal problems (opposition to deepening the Ukrainian-Polish strategic partnership "left" and "right", political reform in Ukraine, etc.), there are objective prospects and interest in the further development of cooperation between our states. Poland uses a strategic partnership with Ukraine in order to gain a more significant position in European and Euro-Atlantic organizations, which would distinguish it from other member states. To this end, official Warsaw decided to take on the role of spokesman for the interests of Eastern Europe, especially Ukraine. Ukraine, for its part, can 
use the partnership with Poland in order to balance historical asymmetries with Russia (especially in the context of modern armed aggression by the latter), gain membership in the European and Euro-Atlantic community, and fully realize its democratic potential ${ }^{14}$. From the analysis of the Ukrainian-Polish strategic relations it follows that they basically came down to observing a common position in regional and European politics. To a large extent, the identical position on issues of pan-European integration made it possible to significantly accelerate the advancement of the North Atlantic Alliance and the European Union to the East. An important reinforcing factor in the process of Ukrainian-Polish rapprochement was also a significant time period necessary for successful European and Euro-Atlantic integration of the two countries. The Ukrainian leadership considered active cooperation with Poland in the political and economic field as a means of accelerating the approach of Ukraine to the structures of the European community. Polish integration into the EU turned out to be one of the main test questions that determined the fate of the declared strategic partnership between the two countries. Finally, on March 1, 1998, the Partnership and Cooperation Agreement between Ukraine and the European Union entered into force, which was to deepen the valley of Polish-Ukrainian integration.

The military-political Ukrainian-Polish cooperation significantly affected the process of forming in-depth bilateral relations, taking into account the expansion of NATO and the activation of the Partnership for Peace program. Since the mid-1990s, Ukrainian-Polish political relations have been building up the political and legal base and are gradually moving to the phase of strategic partnership. Bilateral cooperation of this level has limited the influence of negative factors on the policies of both countries and is consistent with their strategic national interests ${ }^{15}$.

It is the military-political Ukrainian-Polish cooperation, especially given the process of NATO expansion, that is an important guarantee of joint opposition to imperial encroachments on the part of the Russian Federation.

In recent years, especially after the victory of the Dignity Revolution of 2014, Poland willingly acts as the European lobbyist and lawyer of Ukraine, seeks to monopolize the role of the developer of the eastern direction of the EU's "neighborhood policy", fill it with the real prospect

14 Головченко В. Українсько-польські відносини: формування міждержавних взаємин у дусі Євроатлантичного партнерства. WISŁA I DNIEPREM/НАД ВICЛOЮ I ДНIПРОМ. Торунь-Київ: Міжнародний науково-освітній консорииум імені Люсьєна Февра, 2017. Т. 1. С. 49, 50.

${ }^{15}$ Гудзь В., Гудзь В. Політичні відносини України з Республікою Польща наприкінці ХХ століття. WISEA I DNIEPREM/НАД ВICЛOЮ I ДНIПРОМ Польща і Україна в європейській перспективі - минуле і сучасність. Збірник наукових праць на пошану професора Омеляна Вішки (1940-2014). Торунь-Київ: Міжнародний науково-освітній консорцичум імені Люсьєна Февра, 2017. Т. 1. С. 41, 42. 
of full-scale Euro-Atlantic integration and does not mind taking on the role of conductor Ukraine to the mentioned community ${ }^{16}$.

It's hard to deny that the Kremlin regime best anti-Ukrainian hysteria in Poland today, with trampling the Ukrainian flag, ukrainofobskikh of the calls, and the like. It is against this background and the desire to investigate the true circumstances of the accident on April 10, 2010 plane Tu-154 near Smolensk, leveled. However, modern Russia's hybrid war against Ukraine is becoming for the poles is not as relevant. However, as history shows, following the Ukraine may be the same as Poland or the Baltic States. And if not as a direct aggression, then give it a hybrid version.

One of the indicators of a hybrid war in Ukraine is the use of asymmetric fighting, which is characterized by a significant difference in military strength and strategy of the parties involved. From the point of view of international law this strategy is that Ukraine has no formal grounds to fight with the aggressor, who informally support the militants and terrorists. So on the territory of Ukraine acted diversified agents of the intelligence services of the Russian Federation. At the same time, Russia supplies them with weapons and new mercenaries lead shelling of positions of Armed forces of Ukraine from its territory. In an undeclared war against Ukraine, Russia actively uses methods of informationpsychological war, trying to destroy the morale of the troops and the civilian population of the Ukrainian state ${ }^{17}$. At the same time, Kremlin leaders know that Ukraine is not Afghanistan, not Chechnya, and not Syria. An easy walk, given that they lost everywhere, this war will not be. But the geographical proximity, the homogeneity of bureaucracy and business, the corruption of the "elite" play a negative role".

V. Gorbulin noted that the West, for its part, essentially - "washing their hands", allowed all this to happen. Western analysts, in particular Peter Dickinson in their material for the Atlantic Council, are talking more and more clearly about this. He notes that most of the Western media immediately after the Russian aggression against Ukraine suddenly "blinded" about who the aggressor was in the Ukrainian conflict and what the occupation forces should be called, inventing in return some new words and phrases whose only meaning is not to name the Russian aggression as $\operatorname{such}^{19}$.

16 Головченко В. Українсько-польські відносини: формування міждержавних взаємин у дусі Свроатлантичного партнерства. WIStA I DNIEPREM/НАД ВICЛOЮ I ДНIПРОМ. Торунь-Київ: Міжнародний науково-освітній консорииум імені Люсьєна Февра, 2017. Т. 1. С. 43.

17 Парубій А. Війна Росії проти України і світу. Українська Правда. 2014. 6 серпня 2014. URL: http://www.pravda.com.ua/articles/2014/08/6/7034046/

${ }^{18}$ Гай М. Россия знает, что Украина это не Афганистан, не Чечня, не Сирия. Для реальной войны в Украине, РФ должна провести колоссальную подготовку и они это делают. URL: http://patrioty.org.ua/blogs/rossyia-znaet-chto-ukrayna-to-ne-afhanystan-ne-chechnia-ne-syryia-dlia-realnoivoin-v-ukrayne-rf-dolzhna-provesty-kolossalnuiu-podhotovku-y-ony-to-delaiut--hai-140804.html.

19 Горбулін В. Хитромудра невизначеність нового світо порядку. URL: http://gazeta.dt.ua/ internal/hitromudra-neviznachenist-novogo-svitoporyadku-_.html. 
According to Turchenko F. G. Turchenko, the current RussianUkrainian war refers to the type of armed conflict which are called "hybrid", "non-linear", "non-conventional". In wars of this type are used various ways of dealing with the enemy. In General, the characteristics of hybrid wars following: aggression without a formal Declaration of war; concealment of the aggressor of their participation in the conflict; "Information warfare" - propaganda and counter-propaganda using "dirty" information technology; the widespread use of "fifth column" and irregular forces (including under the guise of civilians) the neglect of the aggressor by the international rules of warfare, existing agreements and new agreements; measures of political and economic pressure (in the formal preservation of diplomatic relations between the two countries) confrontation in cyberspace, and the like. Information war of Russia against Ukraine in fact began immediately after the proclamation of independence of Ukraine and has become very aggressive forms since the annexation of Crimea. Actually, it was an attempt to mislead not only the citizens of Ukraine but also the Russian citizens, the international community as a whole ${ }^{20}$.

Most international military experts acknowledge that there is a threat of new conflicts in Europe, and Russian aggression threatens the security of not only Ukraine, but all of Europe. In a hybrid war on one's own territory, it is difficult to defeat, since there are no borders in it. Therefore, it was this factor that influenced the miscalculations of the Ukrainian authorities in conducting the anti-terrorist operation. The Ukrainian-Russian border cannot be blocked if Ukraine does not control the information space and air of the East of Ukraine. At the same time, terrorists will continue to carry out provocations on the border and in occupied territories for informational support to Russian media. The network actions of terrorists in the occupied territory, together with the support of Russian troops at the border, will constantly allow Russia to continue delivering terrorists, weapons and ammunition to Ukrainian territory. Therefore, until the information space in the Donbass is controlled, Ukraine will not be able to count on the support of its own population in the conflict region. Such a situation will contribute to the formation of a permanent social base for the terrorists of the LNV and $\mathrm{DPR}^{21}$.

Thus, it should be noted that most wars are not only armed in military nature, quite often they have a close relationship with the psychological impact on people's minds through agitation, propaganda and other means

${ }^{20}$ Турченко Ф., Турченко Г. Проект «Новоросія» $і$ новітня російсько-украӥнська війнаурченко. К.: Інститут історії України НАН України, 2015. С. 143.

${ }^{21}$ Дацюк С. А. Стратегія перемоги України у війні з Росією. URL: http://blogs.pravda.com.ua/authors/ datsuk/53a5542ba2a4a/. 
of influence. This is especially true of the modern hybrid war unleashed by the Kremlin against Ukraine.

At present, the active opposition of Ukraine to the actions of the Russian Federation, including with the use of military force, has not allowed to fully realize the "Crimean" scenario in the east of our country. In fact, the hybrid war of Russia against Ukraine turned into an armed conflict between the two countries with the direct involvement of troops of both sides. At the same time, despite the attempts of the Russian side to hide the participation of their armed forces in the specified conflict, this fact was recognized by the overwhelming majority of the world community, which led to the strengthening of US and EU sanctions against Russia $^{22}$. And given all this, there is a rhetorical question: isn't it sufficient for poles and Ukrainians to look for in the historical jungle of sedition against one another, blame one another in the former troubles and grievances? At that time, as a common historical enemy - Kremlin regime - and uses any opportunity to the next provocation and inspiration of conflict between poles and Ukrainians.

In General you should summarize that if the result of the First world war was the complete disregard by the major Western countries and political and public-legal interests of the Ukrainian nation, the result of the Second world war this has been true both for Ukraine and for Poland. The confrontation between the two totalitarian States: Germany and the Soviet Union led to a series of tragic consequences for the Ukrainian and the Polish nation. In that time, the Western powers once again ignored the possibility of independent from the Soviet Union the existence of the Ukrainian political nation and the state, and Poland forcibly incorporated into the socialist system, in fact, has become a political vassal of the Soviet Union.

It should be noted that in our time the military-political UkrainianPolish cooperation, particularly given the process of NATO expansion, are crucial to ensure a joint opposition to Imperial encroachments of Russia.

\section{SUMMARY}

An attempt was made to consider to perform Ukrainian-Polish political relations in the context of opposition to the Imperial encroachments of Russia. In particular describes the historical vision of Ukrainian-Polish political relations, given the opposition to the Imperial encroachments of Russia and described the new realities of Ukrainian-

\footnotetext{
22 СИТНИК О. Досвід російсько-української війни 2014-2017 років у контексті україно-польських історичних відносин. NAD WISEA I DNIEPREM/НАД ВICЛOЮ I ДНIПРОМ. Польща і Україна в європейській перспективі - минуле і сучасність. Збірник наукових праць на пошану професора Омеляна Вішки (1940-2014). Торунь-Київ: Міжнародний науково-освітній консорииум імені Люсьєна Февра, 2017. T. 1. C. 185 .
} 
Polish political relations in the process of opposition to the Imperial encroachments of Russia. Traced the joint struggle of Ukraine and Poland for independence and opposition to Russian Imperial expansion.

\section{REFERENCES}

1. Головченко В. Українсько-польські відносини: формування міждержавних взаємин у дусі Євроатлантичного партнерства. WISŁA I DNIEPREM/НАД ВІСЛОЮ I ДНІПРОМ Польща $i$ Україна в європейській перспективі - минуле і сучасність. Збірник наукових пращь на пошану професора Омеляна Вішки (1940-2014). ТоруньКиїв: Міжнародний науково-освітній консорциум імені Люсьєна Февра, 2017. Т. 1. С. 43-51.

2. Дашкевич Я. Україна у вогні ідеологій. Кісь Р. Фінал Третього Риму (Російська ідея на зламі тисячоліть). Львів: Вид-во отців Василіян "Місіонер", 1998. С. I-XIV.

3. Tomaszewski J. Kresy Wschodnie w polskiej mysli politycznej XIX i XX w. Miedzy Polska etniczna a historyczna. Polska mysl polityczna XIX i XX wieku. T. 6. Warszawa, 1988. S. 167-186.

4. Срібняк I. Українська політична еміграція в міжвоєнній Польщі: шляхи формування, особливості діяльності подальша доля. WISŁĄ I DNIEPREM/НАД ВІСЛОЮ І ДНІПРОМ Польщза $і$ Україна в європейській перспективі - минуле $і$ сучасність. Toruń-Saragossa: Міжнародна асоціація істориків-архівістів, 2015. Т. 4. С. 155-159.

5. Поляки i українці між двома тоталітарними системами. 1942-1945. Упорядн.: Б. Гронек, С. Кокін, П. Кулаковський та ін. Редкол.: С. Богунов, М. Вінярчик-Коссаковська, 3. Гайовнічек та ін. Державний архів Служби безпеки України; Архів Міністерства внутрішніх справ і Адміністрації Республіки Польща. Інститут національної пам'яті - Комісія 3 переслідування злочинів проти польського народу; НАН України. Інститут політичних i етнонаціональних досліджень. Варшава; Київ, 2005. Т. 4. Ч. 1. 1512 с.

6. Ситник О. Досвід російсько-української війни 2014-2017 років у контексті україно-польських історичних відносин. NAD WISŁĄ I DNIEPREM/НАД ВІСЛОЮ I ДНІПРОМ. Польща $i$ Україна в європейській перспективі - минуле і сучасність. Збірник наукових працьь на пошану професора Омеляна Вішки (1940-2014). ТоруньКиїв: Міжнародний науково-освітній консорциум імені Люсьєна Февра, 2017. Т. 1. С. 182-185.

7. Гай М. Россия знает, что Украина это не Афганистан, не Чечня, не Сирия. Для реальной войны в Украине, РФ должна провести колоссальную подготовку и они это делают. URL: http://patrioty.org.ua/ blogs/rossyia-znaet-chto-ukrayna-to-ne-afhanystan-ne-chechnia-ne-syryia- 
dlia-realnoi-voin-v-ukrayne-rf-dolzhna-provesty-kolossalnuiu-podhotovkuy-ony-to-delaiut--hai-140804.html

8. Польська Прага: “російська зрада" чи “варшавська авантюра”? Український Форум. URL: http://www.ukrcenter.com/Форум/30401/ Варшавське-Повстання-1944p-та-його-музей

9. Пеленський Я. Україна в польській опозиційній публіцистиці. Подляський Казімєж. Білоруси - литовці - українці: наші вороги - чи брати? Мюнхен. 1986. С. 10-23.

10. Гудзь В., Гудзь В. Політичні відносини України 3 Республікою Польща наприкінці XX століття. WISŁĄ I DNIEPRЕМ/НАД ВІСЛОЮ І ДНІПРОМ Польща $i$ Украӥна в європейській перспективі - минуле і сучасність. Збірник наукових пращь на пошану професора Омеляна Вішки (1940-2014). ТоруньКиїв: Міжнародний науково-освітній консорциум імені Люсьєна Февра, 2017. Т. 1. С. 40-42.

11. Парубій А. Війна Росії проти України і світу. Українська Правда. 2014. 6 серпня 2014. URL: http://www.pravda.com.ua/ articles/2014/08/6/7034046/

12. Гай М. Россия знает, что Украина это не Афганистан, не Чечня, не Сирия. Для реальной войны в Украине, РФ должна провести колоссальную подготовку и они это делают. URL: http://patrioty.org.ua/blogs/rossyia-znaet-chto-ukrayna-to-ne-afhanystanne-chechnia-ne-syryia-dlia-realnoi-voin-v-ukrayne-rf-dolzhna-provestykolossalnuiu-podhotovku-y-ony-to-delaiut--hai-140804.html.

13. Горбулін В. Хитромудра невизначеність нового світо порядку. URL: http://gazeta.dt.ua/internal/hitromudra-neviznachenistnovogo-svitoporyadku-_.html.

14. Турченко Ф., Турченко Г. Проект “Новоросія" $i$ новітня російсько-українська війнаурченко. К.: Інститут історії України НАН України, 2015. 166 с.

15. Дацюк С. А. Стратегія перемоги України у війні з Росією. UR L: http://blogs.pravda.com.ua/authors/datsuk/53a5542ba2a4a/.

\section{Information about the author: Sytnyk O. M.}

Doctor of Historical Sciences, Associate Professor, Head of the Department of History, Archeology and Philosophy, Bogdan Khmelnytskyi Melitopol State Pedagogical University 41/7, Universitetska str., Melitopol, Zaporizhzhia region,

72312, Ukraine 